\title{
The Effect of Classifying Vocabulary into EFL Student's Reading Comprehension
}

\author{
El efecto de clasificar el vocabulario en la comprensión lectora de los estudiantes de \\ Inglés como Lengua Extranjera \\ L'efecte de classificar el vocabulari en la comprensió lectora dels estudiants d'Anglès \\ com a Llengua Estrangera
}

\author{
Rosa Marianella Contreras-Jordán ${ }^{10}$, Rossana María Ramírez-Ávila ${ }^{2, *(0)}$ \\ 1 | Universidad Técnica de Babahoyo, Los Ríos, Ecuador \\ 2 | Universidad Casa Grande, Ecuador \\ *Corresponding author: mramirez@casagrande.edu.ec (Rossana María Ramírez-Ávila)
}

Received: 04/03/2021 | Accepted: 06/02/2021 | Published: 07/19/2021

\begin{abstract}
This study examined the effect of classifying vocabulary into parts of speech using Google Drive sheets in order to improve reading comprehension. Participants were 20 EFL students at a public university in Ecuador whose proficiency level in English was A1 and who were having problems understanding short passages in English. For this action research study, we used quantitative data gathered from pre- and post-surveys, quizzes, and pre- and post-tests. Results from the pre- and post-tests showed that the students improved their word recognition skills by $17 \%$, which enhanced their reading comprehension by $14 \%$. This was corroborated by the $p$-value $=0.000$, which shows that the results were due to classifying parts of speech. Additionally, Cohen's $d=1.02$ in the vocabulary section indicates a large impact on learning. However, there was a small effect size (Cohen's $d=0.39$ ) in reading comprehension. Six quizzes were administered and three of them were compared. These demonstrated a steady improvement in students' meaning recall and word usage. The results of the survey indicate that the students changed their perspective of learning vocabulary positively after the intervention. The implications of this study can be extended to other EFL teachers in higher education institutions who would like to improve their students' reading comprehension. Future research should evaluate other parts of speech. We also recommend replicating this study with students who have a higher proficiency level in English.
\end{abstract}

Citation: Contreras-Jordán, R. M. \& Ramírez-Ávila, R. M. (2021). The Effect of Classifying Vocabulary into EFL Student's Reading Comprehension. Research in Education and Learning Innovation Archives, $27,62-72$. 10.7203/realia.27.20731

Copyright: The Authors. Open Access: This article is distributed under the terms of the Creative Commons Attribution-NoDerivatives 4.0 International licence (CC BY-ND 4.0)

Funding: None informed
KEYWORDS: parts of speech; reading comprehension; word recognition; Google Drive sheets; English as a Foreign Language

RESUMEN: El propósito de este estudio fue examinar el efecto de clasificar el vocabulario en partes del discurso en hojas de Google Drive para mejorar la lectura comprensiva. Los participantes fueron 20 estudiantes de Inglés como Lengua Extranjera de una universidad pública de Ecuador. El nivel de inglés de los estudiantes era A1. Estos tenían problemas comprendiendo pequeñas lecturas en inglés. Esta investigación acción usó datos cuantitativos obtenidos de: encuestas tomadas al inicio y al final, exámenes y pruebas de inicio y final. Los resultados de las pruebas de inicio y final mostraron que los estudiantes mejoraron el $17 \%$ en la sección de reconocimiento de palabras y esto mejoró sus destrezas de comprensión lectora con un $14 \%$ de incremento. Estos resultados fueron corroborados con el valor $p 0.000$ y el valor de Cohen $d=1,02$ en la sección de vocabulario indica un gran impacto en el aprendizaje y hubo un pequeño impacto (Cohen's $d=0,39$ ) en lectura comprensiva. Seis exámenes fueron tomados, tres de ellos se compararon y demostraron una mejora sostenible en la capacidad de los estudiantes para recordar el significado y el uso de las palabras. Los resultados 
de la encuesta indicaron que las perspectivas de los estudiantes en relación al aprendizaje de vocabulario cambiaron positivamente después de la intervención. Las implicaciones de este estudio se extienden a otros docentes de inglés como lengua extranjera de instituciones de educación superior que deseen mejorar la lectura comprensiva de sus estudiantes. Estudios futuros deben agregar otras partes del discurso. Se recomienda probar el mismo estudio en participantes con niveles de inglés más alto.

PALABRAS CLAVE: partes del discurso; lectura comprensiva; reconocimiento de palabras; hojas de Google drive; Inglés como Lengua Extranjera

RESUM: El propòsit d'aquest estudi va ser examinar l'efecte de classificar el vocabulari en parts del discurs en fulls de Google Drive per a millorar la lectura comprensiva. Els participants van ser 20 estudiants d'Anglès com a Llengua Estrangera d'una universitat pública de l'Equador. El nivell d'anglès dels estudiants era A1. Tenien problemes comprenent petites lectures en anglès. Aquesta investigació acció va usar dades quantitatives obtingudes de: enquestes preses a l'inici i al final, exàmens i proves d'inici i final. Els resultats de les proves d'inici i final van mostrar que els estudiants van millorar el $17 \%$ en la secció de reconeixement de paraules i això va millorar les seues destreses de comprensió lectora, amb un $14 \%$ d'increment. Aquests resultats van ser corroborats amb el valor $p$ 0.000 i el valor de Cohen $d=1,02$ en la secció de vocabulari indica un gran impacte en l'aprenentatge, i va haver-hi un impacte petit (Cohen's $d=0,39$ ) en lectura comprensiva. Es van fer sis exàmens, tres es van comparar i van demostrar una millora sostenible en la capacitat dels estudiants per a recordar el significat i l'ús de les paraules. Els resultats de l'enquesta van indicar que les perspectives dels estudiants en relació a l'aprenentatge de vocabulari van canviar positivament després de la intervenció. Les implicacions d'aquest estudi s'estenen a altres docents d'anglès com a llengua estrangera d'institucions d'educació superior que desitgen millorar la lectura comprensiva dels seus estudiants. Estudis futurs han d'agregar altres parts del discurs. Es recomana provar el mateix estudi en participants amb nivells d'anglès més alt.

PARAULES CLAU: parts del discurs; lectura comprensiva; reconeixement de paraules; fulls de Google Drive; Anglès com a Llengua Extrangera

\section{Practitioner Notes}

What is already known about this topic

- Students lack of vocabulary knowledge

- Students are not used to reading

- Students should understand at least $98 \%$ of words to understand texts

What this paper adds

- Classifying parts of speech to help students recall meaning and use of words in context

- Learning more vocabulary in context aids in students' reading comprehension

- Perspectives of students' change with the implementation of this type of word recognition strategy

\section{Implications for practice and/or policy}

- Other EFL teachers may benefit from replicating this study

- Word recognition strategies should be implemented to improve students' reading comprehension

\section{INTRODUCTION AND REVIEW OF THE LITERATURE}

Results of international and local tests that involve reading in L1 are low. The Program for International Student Assessment (PISA) evaluates the quality, equity, and efficiency of educational systems. Seventy-two countries around the world are within this program. This program has evaluated 540,000 fifteen-year-old students. The international average (72 countries included) for reading comprehension was 493 from the total grade that was 1000 (OCDE, 2016). Flotts et al. (2015), in the Third Regional 
Comparative and Explanatory Study (TERCE, abbreviation in Spanish), evaluated primary schools from Latin America and the Caribbean. Fifteen countries and the state of Nuevo Leon - Mexico were assessed. The sample represented 170,097 third-grade students and 229,447 sixth-grade students. Regarding reading, countries with an average below the mean were Ecuador, Guatemala, Honduras, Nicaragua, Panama, Paraguay, and Dominican Republic (third and sixth grade). Among all countries, there were $60 \%$ and $72 \%$ of students in levels I and II, in third and sixth grade, respectively. In Ecuador, $62 \%$ and $77 \%$ of the students were in level I (Students can find repeated and isolated information with one meaning) and II (Students can find information in a short text, identify synonyms, recognize simple phrase reformulation and redundancies between graphic and verbal codes) in L1 reading comprehension, 3rd and 6th grade respectively. This means that students had very low reading levels in L1 generally.

Regarding reading in English as a foreign language, a study conducted by the British-Council (2015) reported that respondents with basic reading skill claimed it was because they did not read in English frequently enough (45\%), others said they had not been studying English very long (28\%), and almost a quarter of Ecuadorian English learners said for different reasons related to the education system constraints. On the contrary, learners who reported having good reading skills said that it was because they practiced reading on their own (43\%), others for their education in English language schools (17\%), and a few of them because of the use of social media in English (14\%).

Ecuadorian learning standards (Ministerio-De-Educación, 2012) state that students should have a B1 English proficiency level when they enter the university, but the reality is that they barely have an A1 level in the public university where this study was developed. This university is located in the urban area and students generally belong to the middle class. The researcher has worked in the place of study for four years and diagnostic tests have always been a requirement. These tests showed students having no more than A1 proficiency level. In this respect, the British-Council (2015) pointed out that even though bachelor's students graduate with B1, there were not any English requirements to enter university. Thus, this study aimed at students' real proficiency level, which was A1. According to the Ecuadorian learning standards, A1 students can understand and identify easy information, familiar names, words, and basic vocabulary. Regarding reading strategies, students should be able to come up with the main ideas and identify key information of basic texts (Ministerio-De-Educación, 2012). This level was provided after a proficiency test. The test was developed by an international recognized institution (MM-Publications, 2021). It places students from A1 to C1. It was chosen due to its availability and facility. Additionally, students receive the scores in their mail.

This study was conducted in a public university in Babahoyo city. Most students in this institution come from public high schools. Students' ages ranged from 17 to 30 years old. In a pilot sample, students filled out a survey about their vocabulary and reading perspectives. Most of the students (57\%) disagreed on understanding a text with the first reading; $71 \%$ of the students agreed that they understood a short text by rereading it; $57 \%$ of the students agreed on getting an idea about the content of simple informational material with visual support; and, $79 \%$ of the students agreed on getting an idea of the content of short simple descriptions with visual support. However, in the open-ended questions of the survey, some students wrote that English words were not easy because they are written differently from their pronunciation, and some words are strange and confusing. Participants indicated they did not use the language outside the classroom. Even though students said they understood short texts, they also mentioned feeling stressed, confused, and scared when they saw a passage and did not know the meaning of the words. These preliminary results motivated this study which aim was to apply a vocabulary intervention to improve reading comprehension. The 
research objectives were to determine if students improve their vocabulary knowledge, if they improve their reading comprehension in English as Foreign Language (EFL), and their perspectives towards vocabulary and reading comprehension.

Regarding vocabulary, Spratt, Pulverness, and Williams (2005) defined it as an individual or group of words which have their meaning according to the context. I. S. P. Nation (2001) suggested teaching vocabulary by deliberate instruction of form, use, or meaning. This study focuses on the form and meaning. The parts of speech that were considered for this study were the following: nouns, verbs, adjectives, and adverbs. Sonbul and Schmitt (2009) stated that direct and explicit vocabulary instruction within reading passages is the best pedagogical technique for constructing a vast range of L2 vocabulary and consequently to improve reading proficiency.

Pang, Muaka, Bernhardt, and Kamil (2003) stated that reading is a complex process associated with personal judgement and thought. They added that the process of reading involves word recognition and comprehension. Word recognition is noticing the written word, the spoken language, and comprehension to be knowledgeable with the meaning of the text. Spratt et al. (2005) mentioned that knowing a word involves meaning in context, form and use.

Suleiman-Alyousef (2006) highlighted that reading comprehension is an interactive process between the reader and the text in which different processes take place. For this author, the first process is the automatic recognition of the content. Glenberg (2011), "reading comprehension, much like comprehension of situations and comprehension of oral language, is embodied" (p.5) which means that comprehension includes taking action about the physical world, individual objectives, and cultural background. Burrows and Holsworth (2016) conducted a study about how word recognition technique helped to improve reading comprehension in Japanese students. They concluded that it should be permanently practiced in classrooms.

Some studies have proven that gaining vocabulary through word recognition skills improves students'reading performance. Cuadro, Balbi, and Luis (2017) demonstrated in their research that precise and fluid word recognition has a great incidence on students' reading comprehension because of the speed in which students get the accurate comprehension answers. In fact, K. Nation and Snowling (1998) stated that children with reading comprehension difficulties had weaker semantic skills causing a restriction for word recognition development. Li and Kirby (2014) analyzed the relationship between vocabulary repertoire and vocabulary meaning knowledge with English reading in Chinese students. They said that "both breadth and depth of vocabulary are required for adequate L2 word reading and reading comprehension" (p. 631).

For the purpose of word recognition, Google sheets were used. Firth and Mesureur (2010) stated that Google drive is useful for teaching assignments management, reporting grades, extensive reading, homework production and submission, self and peer assessment, feedback, and collaborative writing. They added that Google drive is a free online tool given by Google. Users can share documents and work collaboratively in real time. It also gives the opportunity to store documents in the cloud hosted on the internet. This tool has Google docs, sheets, and slides. Brescó and Verdú (2014) assessed the use of collaborative tools such as Wikispaces and Google drive in higher education, Google drive obtained better outcomes for communication and organizing work. Furthermore, Moore (2016) emphasized Google Drive as an effective tool, to prepare students for the job market and to be competitive workers.

Teh and Morgan (2005) mentioned that the sheets serve to organize and visualize data in a friendly way. Most of the studies in which sheets were used are related to statistics (Lee, Park, Choi, \& Kim, 2016; Siddamsetty, Siddamsetty, \& Sivasankar, 2017) or any other numerical subject (Uddin, Ahsanuddin, \& Khan, 2017), or even to teach technology (Willis, 2016) but there is not research in which sheets were used for learning a language. 
The next step, after word recognition, was that students read and comprehend the content of the text. For that purpose, two strategies are well-recognized to improve reading comprehension: skimming and scanning. Regarding skimming, Spratt et al. (2005) stated that it aims at a general background about the text. Ngoc (2015) emphasized that it allows readers to get the core of a text superficially. The same authors described scanning as a subskill which helps students to look for specific information. Ngoc (2015) established that scanning follows three steps: define the keywords needed, search these words rapidly in the text, and read the content around them to see if they give the information the reader is looking for.

Lastly, students' perceptions of the use of Google drive was also investigated. Brescó and Verdú (2014); Sadik (2016) reported that students' perspectives were positive regarding the use of Google drive. They perceived it as an easy, user-friendly, and useful tool for academic tasks. Students' attitudes towards using Google drive focused on communication or work organization.

After the literature review, the following gaps have been found in the research: There are not research studies regarding reading in higher education that have explored parts of speech, skimming, and scanning; research included here were applied in international contexts not locally; and, there are not studies that have been implemented to test the effectiveness of Google drive sheets to learn vocabulary in EFL contexts.

\section{MATERIALS AND METHODS}

Action Research (AR) was chosen to conduct this study. According to Dick (2015), $\mathrm{AR}$ is a set of allied processes which applies different methods and tools in order to provoke a change; and this adjustment should imply an improvement in a specific issue. Thus, this study is an AR with quantitative and qualitative analysis.

\subsection{Participants}

The convenient sample was one group of 20 students. They were in one class that was assigned to the teacher and corresponded to the fourth out of six levels of English available. All the students attended a public university located in Ecuador. Regarding the placement test results, students' English level was A1 according to the CEFR (Common European Framework of Reference). It seems students completed the requirements to pass the previous level but their level was not improving the way it should. In the fourth level, students should demonstrate an A2 level.

Most of the participants were female (80\%), their socioeconomic background was low to medium mostly, and the majority were between 17 and 22 years old (75\%). Moreover, students reported having access to technology from home (90\%). The institution did not have free internet connection for students. The computer laboratory was not always available. This sometimes was a constraint in this study.

\subsection{Instruments}

To draw the sample characteristics, a demographic survey was taken to describe the 20 participants. The demographic survey contained nominal data such as gender, yes-no questions, and open-ended questions; ordinal data like the knowledge they had about technology and English proficiency level.

Because of the researcher's own experience, classes are multilevel. Due to that fact, an English proficiency test was taken to elaborate the lesson plan according to student's actual level. The proficiency English test was taken online through https:// www.mmpublications.com/Online-Placement-Test which is a free test.

To answer the first research question: To what extent will students classify vocabulary into parts of speech correctly? A pretest and posttest was applied. It was a 
reading exercise. The reading was taken from an open access website (https://www .usingenglish.com/comprehension/10.html). It was adapted by the researcher. Since this reading originally aimed at intermediate level students, the researcher changed some tenses and words in order to adapt it to an A1 level text. The researcher added classification and skimming exercises to meet the study objective. The test focused on the classification of parts of speech and vocabulary usage. The classification of words section was out of 30 points and the usage section was out of seven points giving a total score of 37 points. The test was validated by three EFL experts.

To support the results of the pre and posttest, three mini vocabulary quizzes were taken and they consisted in three open questions. The first instruction involved students to write the words they remembered, the second question was to give the meaning of the same words, and the third one was to use those words in sentences.

To answer the second research question: To what extent will students improve their reading comprehension? A reading comprehension pre -posttest was used. This test focused on skimming, scanning, and comprehension exercises. In the first part, there were open questions in which students had to skim the text. The maximum score was six points. The second part had scanning exercises. The maximum grade in this section was seven. The two sections of this test added a total score of 13 points.

To answer the third question: What are students' perspectives in classifying parts of speech to improve reading comprehension? A pre and post vocabulary survey was used. It was adapted from Almache and Ramírez-Ávila (2020). The Cronbach Alpha of the survey was 0.903 for the pretest and 0.902 for the posttest. This survey asked students to check if they considered learning vocabulary was complex or not, there was a "neutral" option, too.

\section{DATA ANALYSIS}

For quantitative questions (No. 1 and 2), the grades of the instruments (pre- posttests) were transferred to the SPSS program. Descriptive statistics were calculated: minimum, maximum, mean, and standard deviation. The effect size was calculated to know the magnitude of the treatment and determine if the impact of the innovation was null, small, intermediate, or large. Then, the researcher calculated the t-test for related samples in SPSS for comparing the means of the pre and posttest. A value of $\mathrm{p} \leq 0.05$ determines a strong evidence that changes after the innovation are due to the intervention.

To answer the third question, a survey was applied to determine students' perspectives towards vocabulary. Pre and post survey reliability was tested by Cronbach alpha. Items from the survey were classified in complex, neutral, and not complex according to students' perspectives. After, students' answers were tabulated in each denomination. Finally, these results were translated in percentage to analyze how results changed after the intervention.

\subsection{Classroom Procedures}

This was an AR. After determining the problem that students had with reading comprehension in EFL, the teacher chose one class that was assigned to her to apply the intervention. It consisted of classifying words into parts of speech to improve reading comprehension using Google Drive sheets. It was applied for seven weeks, four hours per week which means 28 hours in total in one class of 20 students. A backward design plan was developed for this purpose. Within these 28 hours, two hours were assigned for training students to use Google sheets, and two hours for the final assessment task. Students did five hours of autonomous work with five assignments for classifying parts of speech. The classification of the words was done in groups in a shared sheet. For this task, the laboratory of the institution was used. Since 
the lab was not always available for different reasons, some sessions were conducted in the classroom. Students classified the words using posters.

The final authentic task was a piece of writing about an invention. Students used the words that were in their spreadsheet. A rubric was used to grade this composition. The characteristics containing the rubric were the number of new words, correct usage of the words, and length of the paragraph.

In the first week, students had a short training about how to use Google Drive and the sheets. Most of the students did not know the tool, or they had just heard about it, but not used it. During this time, they also learned about the parts of the speech (noun, verb, adjective, and adverb), meaning and function in context.

In the following weeks, reading exercises were scaffolded with a skimming and scanning form. Students used this form in following passages. After each reading practice, students added words on the sheets in groups while they were in the classroom, and individually at home. Some activities were held to learn new vocabulary such as acting out, trivia, visuals, Pictionary, and spelling games. The content was based on the textbook, to cover the syllabus, but it was enriched with authentic material and tasks. Students worked collaboratively in pairs and groups to infer meaning through pictures or statements.

\section{ANALYSIS AND RESULTS}

The results of the study are presented according to the research questions. The first research question: To what extent will students classify vocabulary into parts of speech correctly? The data was classified in word recognition (parts of the speech classification) and the use of the same words, it is shown in Table 1.

Table 1. Classification and Usage of Vocabulary in pre and post-tests. Source: Author

\begin{tabular}{|c|c|c|c|c|c|c|}
\hline & \multicolumn{3}{|c|}{ Pre-test } & \multicolumn{3}{|c|}{ Posttest } \\
\hline & Min & Max & $\mathrm{M}(\mathrm{SD})$ & Min & Max & $\mathrm{M}(\mathrm{SD})$ \\
\hline Classification & 2.727 & 21.818 & $10.055(4.123)$ & 5.455 & 24.545 & $15.486(6.086)$ \\
\hline Usage & 1.556 & 5.444 & $3.100(1.316)$ & 1.556 & 7.000 & $3.961(1.850)$ \\
\hline
\end{tabular}

Table 1 shows that there was an improvement in classification (10.055-15.486) and in the usage (3.100 - 3.961) according to the means. Overall, there was an improvement of 6 points $(13.15-19.44)$ in the vocabulary section. Finally, Cohen's $d=1.02$ means there was a large effect size.

During the implementation of the strategy, students did three quizzes, each quiz had three categories: number of words, meaning, and usage. Results of progress are shown in Table 2.

Table 2. Progress of students' knowledge of vocabulary. Source: Author

\begin{tabular}{|c|c|c|c|c|c|c|c|c|c|}
\hline & \multicolumn{3}{|c|}{ Quiz 1} & \multicolumn{3}{|c|}{ Quiz 2} & \multicolumn{3}{|c|}{ Quiz 3} \\
\hline & Min & Max & $\mathrm{M}(\mathrm{SD})$ & Min & Max & $\mathrm{M}(\mathrm{SD})$ & Min & Max & $\mathrm{M}(\mathrm{SD})$ \\
\hline Words & 2 & 10 & $4.15(1.725)$ & 1 & 7 & $4.00(1.589)$ & 1 & 7 & $4.35(1.872)$ \\
\hline Meaning & 0 & 6 & $3.45(1.395)$ & 1 & 7 & $3.40(1.698)$ & 1 & 7 & $3.55(1.538)$ \\
\hline Usage & 0 & 4 & $2.25(1.251)$ & 1 & 6 & $2.55(1.468)$ & 1 & 7 & $3.00(1.686)$ \\
\hline
\end{tabular}

As shown inTable 2, the average in the number of words and meaning that students remembered after class sessions was improved slightly. Concerning the word usage, 
students had an increase from 2.25 to 3.00 in quizzes 1 and 3 respectively, being this section the one they progressed the most. The reason this instrument demonstrated a small upgrade compared to the results of the vocabulary pre and posttests could be the type of exercises in the instruments. In the pre and posttest, students had to classify the underlined words in a given text and then matched them in sentences. On the other hand, in the quizzes students had to remember the words, explain the meaning and then make sentences with them, making the quizzes more difficult in their development. This constant practice may have impacted students' retention of vocabulary knowledge, and affected the results of the vocabulary and reading comprehension tests.

The second research question: To what extent will students improve their reading comprehension? It is answered through general descriptive statistics shown in Table 3.

Table 3. Results for reading comprehension. Source: Author

\begin{tabular}{lcccccc}
\hline & \multicolumn{2}{c}{ Pre-test } & \multicolumn{4}{c}{ Posttest } \\
& Min & Max & M(SD) & Min & Max & M(SD) \\
\hline Skimming & 1.000 & 6.000 & $3.399(1.418)$ & 2.000 & 6.000 & $3.750(1.446)$ \\
Scanning & 2.000 & 6.000 & $4.450(1.191)$ & 3.000 & 6.000 & $4.900(1.021)$ \\
Total & 4.000 & 12.000 & $7.750(2.414)$ & 6.000 & 12.000 & $8.650(2.183)$ \\
\hline
\end{tabular}

As Table 3 shows, there was a slight improvement in skimming (pretest 3.399 posttest 3.750) and scanning (pretest 4.450 - posttest 4.900) according to their means. Overall, there was an improvement of 0.9 points in the reading comprehension section. Finally, Cohen's $d=0.39$ determined a small effect size.

The $\mathrm{t}$-test was run to get the $\mathrm{p}$ value. It is $\mathrm{p}=.000<0.05$ which means that the difference between the means is significant in relation to before and after the intervention, it was not by chance. It showed that the means were different. To corroborate that the means were statistically different, the $t$ value was obtained (-6.545). It is the result of the division between the mean difference and the standard error mean.

The third research question: What are students' perspectives in classifying parts of speech to improve reading comprehension? A comparison of students' perspectives was done between the pre and post surveys. At the beginning, $40 \%$ of the students thought it was complex in the pre-survey but this percentage decreased to $25 \%$ in the post survey. On the other hand, the percentage of students that thought vocabulary was not complex increased from $15 \%$ (in the pretest) to $45 \%$ in the post survey. The rest of the students were neutral about their perspectives towards vocabulary (presurvey $=45 \%$, post-survey $=30 \%$ ). These results indicate that students changed their perspectives positively after the intervention.

\section{DISCUSSION AND CONCLUSIONS}

Regarding the first question: To what extent will students classify vocabulary into parts of speech correctly? Findings showed that there was an improvement of $18 \%$ in classification and $16 \%$ in the usage of the vocabulary, so the classification was slightly better developed by students. These results may have been the result of focusing on the use and form of the vocabulary which I. S. P. Nation (2001) recommended teachers for vocabulary instruction. Additionally, Richards (2006) mentioned, taking advantage of mistakes is an effective principle to learn a language. It was an ally to make students learn the difference between adjectives and adverbs, given than these two items the most difficult to recognize according to the researcher's observation. Even though there was a low improvement, students became aware of the differences of two parts of speech that they sometimes confused. 
The improvement can also be attributed to the collaborative work done by students. They had to add new words and classify them into their parts of speech, according to the context. This work was done through the shared sheet in Google. Collaboration was one of the facilities of using a shared document in Google listed by Brescó and Verdú (2014); Firth and Mesureur (2010) also reported better results using Google drive in higher education.

To get these positive results explicit vocabulary instruction was applied in the innovation. Using dictionaries and making students pay direct attention to the meaning and use of the words were the keys for their learning, as Sonbul and Schmitt (2009) stated, the explicit vocabulary instruction is an appropriate technique for students with low proficiency level. Moreover, the process on how students developed their vocabulary range was analyzed through quizzes. The results demonstrated that students did not remember more words after classes, but they were aware of the meaning and they could use them. These results may not be related to the ones in the pre and posttests because the design of the quizzes and tests were totally different. Being a group with A1 proficiency level, open questions in the quizzes could have been more difficult to answer than the ones that were multiple choice in the tests.

Regarding the second research question: To what extent will students improve their reading comprehension? Despite reading being a complex process Pang et al. (2003), results showed that students improved in finding main ideas and specific information. So, students improved their reading comprehension by $14 \%$. This achievement is aligned to the Ecuadorian learning standards (2012) in which students are able to comprehend and recognize easy vocabulary and apply skimming and scanning strategies. This demonstrated that applying word recognition technique in the classroom helped students to improve their reading comprehension skill as it has been demonstrated in other research studies (Burrows \& Holsworth, 2016; Cuadro et al., 2017; Li \& Kirby, 2014). Burrows and Holsworth (2016) recommended teachers to practice recognition techniques to improve reading comprehension. Other authors (Cuadro et al., 2017; Li \& Kirby, 2014) also agreed that there is an impact of word recognition in reading and reading comprehension. They highlighted that it raises fluency in reading. Pang et al. (2003) pointed out that word recognition and comprehension are part of reading. K. Nation and Snowling (1998) implied the impact of restricted word recognition development in reading comprehension. Suleiman-Alyousef (2006) highlighted the interaction between the reader and the text. In this study, students read the passages different times to determine the meaning of the words in context. Later, they saw the same word in the shared sheet. Thus, this interaction and constant work with vocabulary may have also had an effect in students' reading comprehension.

Lastly, the third question: What are students' perspectives in classifying parts of speech to improve reading comprehension? Findings showed that students changed positively their perspective about learning vocabulary. They went from $15 \%$ of the students considering vocabulary as not complex in the pre-survey to a positive position in which they set vocabulary as not complex $(45 \%)$ in the post-survey. Students proved to be comfortable using Google Drive sheets. Even though it was a new tool for most of them, the researcher observed that students enjoyed working with Google sheets in the classroom. The same results can be compared to other studies (Brescó \& Verdú, 2014; Sadik, 2016).

The aim of this study was to prove how learning parts of the speech and the correct use of the vocabulary could improve students' reading comprehension skills. Based on the evidence, word recognition and use were useful to improve reading comprehension skills such as skimming and scanning.

It can be concluded that even though there was an improvement in both vocabulary and reading comprehension, students performed better in vocabulary knowledge than in reading comprehension skill, but this result could have been diminished because of 
the number of the items in the pre and posttest. There were 37 items for vocabulary and 13 for reading comprehension. Thus, fewer items meant less opportunities for students to succeed in the task. This is also related to the quizzes instrument in which students could not perform as well as they did in the test (vocabulary section), due to the open question design, learners could not develop their knowledge fully.

An important finding was that adjectives and adverbs were the most difficult for students to differentiate, but it was good to keep students' attention at the beginning. Once students identified the difference they got bored with the same repeated classification methodology. Thus, it is recommended to add other parts of speech. Students learned the difference during the seven weeks that this implementation lasted. They were also more confident about learning vocabulary.

Regarding the use of technology, students did not know how to work on shared documents like sheets. At the end, they also perceive Google drive sheets as an easy and friendly tool. This may have prepared them to work online in the current situation due to Covid-19.

This intervention was applied in a short period of time which coincided with the Christmas holiday. There were other extra-curricular activities going on. However, results demonstrated a large impact for learning vocabulary and a small impact for reading comprehension. Thus, it can be inferred that if the intervention is applied over longer period of times the impact can be higher.

All in all, reading comprehension can be raised with the awareness of parts of speech combined with technology. Thus, findings in this study may well serve the EFL community to pay attention to receptive skills to upgrade students' English level and assist them in reaching the levels according to the standards set by authorities.

\section{REFERENCES}

Almache, G., \& Ramírez-Ávila, M. (2020). Classifying vocabulary in Google sheets to improve words recognition and reading comprehension in EFL learners: An action research study. AtoZ, 9(2), 24-31. http://dx.doi.org/10.5380/atoz.v9i2.73526

Brescó, E., \& Verdú, N. (2014). Valoración del uso de las herramientas colaborativas Wikispaces y Google Drive, en la educación superior. Edutec. Revista Electrónica de Tecnología Educativa, 49, 1-12. https://doi.org/10.21556/edutec.2014.49.39

British-Council. (2015). English in Ecuador An examination of policy, perceptions and influencing factors. Retrieved from https://www.teachingenglish.org.uk/sites/teacheng/ files/English\%20in\%20Ecuador.pdf

Burrows, L., \& Holsworth, M. (2016). The Effects of Explicit Word Recognition Training on Japanese EFL Learners. Reading Matrix: An International Online fournal, 16(2), 81-97. Retrieved from http://www.readingmatrix.com/files/15-53i723q2.pdf

Cuadro, A., Balbi, A., \& Luis, A. (2017). Acceso léxico y lectura de textos en estudiantes universitarios. Revista Electrónica de Investigación Educativa, 19(4), 1-8. https://doi.org/ 10.24320/redie.2017.19.4.1282

Dick, B. (2015). Reflections on the SAGE Encyclopedia of Action Research and what it says about action research and its methodologies. Action Research, 13(4), 431-444. https:// doi.org/10.1177/1476750315573593

Firth, M., \& Mesureur, G. (2010). Innovative uses for Google Docs in a university language program. The fALT CALL fournal, 6(1), 3-16. https://doi.org/10.29140/jaltcall.v6n1.88

Flotts, M. P., Manzi, J., Jiménez, D., Abarzúa, A., Cayuman, C., \& García, M. J. (2015). Informe de resultados TERCE: logros de aprendizaje.

Glenberg, A. M. (2011). How reading comprehension is embodied and why that matters. International Electronic fournal of Elementary Education, 4(1), 5-18. Retrieved from https:/www.iejee.com/index.php/IEJEE/article/view/210 
Lee, S. B., Park, J., Choi, S. H., \& Kim, D. J. (2016). Re-exploring teaching and learning of probability and statistics using Excel. Journal of the Korea Society of Computer and Information, 21(7), 85-92. Retrieved from https://scienceon.kisti.re.kr/srch/ selectPORSrchArticle.do?cn=JAKO201624238396807

Li, M., \& Kirby, J. R. (2014). The Effects of Vocabulary Breadth and Depth on English Reading. Applied Linguistics, 36(5), 611-634.

Ministerio-De-Educación. (2012). Estándares de educación de calidad. Aprendizaje, Gestión Escolar, Desempeño Profesional e Infraestructura. Retrieved from https://educacion.gob .ec/wp-content/uploads/downloads/2013/03/estandares_2012.pdf

MM-Publications. (2021). MM Online Placement Test. London. Retrieved from https://www mmpublications.com/online-placement-test

Moore, C. (2016). The Future of Work: What Google Shows Us About the Present and Future of Online Collaboration. TechTrends, 60(3), 233-244. http://dx.doi.org/10.1007/s11528 $-016-0044-5$

Nation, I. S. P. (2001). Learning Vocabulary in Another Language. Cambridge: Cambridge University Press.

Nation, K., \& Snowling, M. J. (1998). Semantic Processing and the Development of WordRecognition Skills: Evidence from Children with Reading Comprehension Difficulties. fournal of Memory and Language, 39(1), 85-101. https://doi.org/10.1006/jmla.1998.2564

Ngoc, N. T. M. (2015). The essential roles of Skimming and Scanning Techniques in teaching reading comprehension. Retrieved from http://nnkt.ueh.edu.vn/wp-content/uploads/ 2015/07/20.pdf

OCDE. (2016). Programme for International Student Assessment 2015 Results. Excellence and Equity in Education (Vol. 1). Paris: OECD Publishing.

Pang, E. S., Muaka, A., Bernhardt, E. B., \& Kamil, M. L. (2003). Teaching reading (Vol. 12). Brussels: International Academy of Education.

Richards, J. C. (2006). Communicative language teaching today. New York: Cambridge University Press.

Sadik, A. (2016). Students' acceptance of file sharing systems as a tool for sharing course materials: The case of Google Drive. Education and Information Technologies, 22(5), 2455-2470. https://doi.org/10.1007/s10639-016-9556-Z

Siddamsetty, U., Siddamsetty, M., \& Sivasankar, R. P. (2017). Two-way ANOVA Calculations Using MS-Excel. Research fournal of Science and Technology, 9(4), 532-532. http:// dx.doi.org/10.5958/2349-2988.2017.00091.2

Sonbul, S., \& Schmitt, N. (2009). Direct teaching of vocabulary after reading: is it worth the effort? ELT fournal, 64(3), 253-260. https://academic.oup.com/eltj/article/64/3/253/ 434203\#: :text=https\%3A//doi.org/10.1093/elt/ccp059

Spratt, M., Pulverness, A., \& Williams, M. (2005). The TKT teaching knowledge test course. Edinburgh: Cambridge University Press.

Suleiman-Alyousef, H. (2006). Teaching reading comprehension to ESL/EFL learners. Language learning journal, 5(1), 63-73.

Teh, K., \& Morgan, L. (2005). The application of Excel in teaching finite element analysis to final year engineering students. Proceedings of the 2005 ASEE/A aeE 4th Global Colloquium on Engineering Education, 1-10. Retrieved from https://citeseerx.ist.psu .edu/viewdoc/download?doi=10.1.1.471.7717\&rep=rep1\&type=pdf

Uddin, Z., Ahsanuddin, M., \& Khan, D. A. (2017). Teaching physics using Microsoft Excel. Physics Education, 52(5). Retrieved from https://iopscience.iop.org/article/10.1088/ $1361-6552 / \mathrm{aa} 7919 / \mathrm{pdf}$

Willis, V. F. (2016). A model for teaching technology: Using Excel in an accounting information systems course. Journal of Accounting Education, 36, 87-99. https:// doi.org/10.1016/j.jaccedu.2016.05.002 